\title{
Potentiometric Determination of Minoxidil in Topical Use Pharmaceutical Samples
}

\author{
Rogério Adelino de Sousa ${ }^{1}$, Éder Tadeu Gomes Cavalheiro ${ }^{2 *}$ \\ 1 - Departamento de Química, Universidade Federal de São Carlos, Rod. Washington Luiz Km 235, São Carlos, São Paulo, Brasil, CEP \\ 13565-905, Caixa Postal 676. \\ 2 - Departamento de Química e Física Molecular, Instituto de Química de São Carlos, Universidade de São Paulo, Av Trabalhador São- \\ carlense, 400, Centro, São Carlos, São Paulo, Brasil, CEP 13560-970, Caixa Postal 780. \\ *cavalheiro@iqsc.usp.br
}

\begin{abstract}
A potentiometric titration method for the determination of minoxidil based on its redox reaction with $\mathrm{K} 2 \mathrm{Cr} 2 \mathrm{O} 7$ is described. The best results were observed using $1.00 \times 10-3 \mathrm{~mol}$ L-1 K2Cr2O7 and $1.00 \times 10-2$ mol L-1 minoxidil solutions, and the minoxidil as titrant in 2.00 mol L-1 H2SO4 medium. The method was applied to commercial samples and compared with the results from a chromatographic procedure. Recoveries from 97.4 to $98.7 \%$ were observed depending on the sample. Comparison with the chromatographic procedure reveled agreement within $90 \%$ confidence level.
\end{abstract}

Keywords: Minoxidil determination; titration; potenciometry.

\section{Introduction}

Minoxidil (2,4-diamino-6-piperidinopyrimidine-3-oxide) is an odorless white crystalline powder, insoluble in water, acetone or alkaline solutions, slightly soluble in alcohols, and freely soluble in acidic solutions [1]. It has been used as a peripheral vasodilator drug orally administrated, applied in the treatment of refractory hypertension patients [2] and liquid retention and hirsutism is being observed for excessive doses [3].

Minoxidil also shows new applications in dermatology, especially in the treatment of androgenic alopecia [3,4]. In this case, this drug has been topically applied in order to stimulate hair growth by inducing vasodilatation and increasing the local irrigation and blood flow [4].

Commercially available products typically contain $2 \%$ minoxidil $(\mathrm{m} / \mathrm{v})$, in topic use formulations, containing ethanol, and propylene glycol, or their mixture with 2-n-nonyl-1,3-dioxolane as a vehicle [5,6].

Concerning analytical methods, $\mathrm{MnO}_{4}^{-}$has been proposed for the oxidimetric titration of minoxidil [2,7-8]. In addition, several instrumental techniques have been described for minoxidil determination in matrixes such as serum and pharmaceutical products. Most of them are based in chromatographic methods as described in references [3, $9-12]$.

Potentiometric titration [13,14] using $\mathrm{K}_{2} \mathrm{Cr}_{2} \mathrm{O}_{7}$ is proposed in this paper. High purity $\mathrm{K}_{2} \mathrm{Cr}_{2} \mathrm{O}_{7}$ is available, it is thermally stable and standard solutions can be prepared, stable to the action of light. It is not reduced by hydrochloric acid $(\mathrm{HCl})$, reacts with organic matter being reduced from $\mathrm{Cr}(\mathrm{VI})$, orange, to $\mathrm{Cr}(\mathrm{III})$, green, according to the half-reaction (Eq. 1) $[15,16]$.

$$
\mathrm{Cr}_{2} \mathrm{O}_{7}^{2-}+14 \mathrm{H}^{+}+6 \mathrm{e}^{-} \rightarrow 2 \mathrm{Cr}^{3+}+7 \mathrm{H}_{2} \mathrm{O}
$$

$\mathrm{E}^{\mathrm{o}}=1,33 \mathrm{~V} \quad$ (Eq. 1 ) 


\section{Experimental}

\section{Reagents and Solutions}

All the reagents were of analytical grade and used as received. Solutions were prepared using water bi-distilled in quartz stiller. Potassium dichromate (Merck, Germany) solutions were prepared by direct dissolution of the salt in $\mathrm{H}_{2} \mathrm{SO}_{4}$ solution (2.00 mol L-1). Minoxidil was from Natural Pharma (Brazil), and $\mathrm{H}_{2} \mathrm{SO}_{4}$ from Mallinckrodt (Mexico).

\section{Potentiometric methods}

Potentiometric titrations were performed within an glass cell containing a platinum electrode (indicator) and a saturated calomel electrode (reference) and a pH-meter Corning M 425 (Corning, USA)

$10.00 \mathrm{~mL}$ of a $1.00 \times 10^{-3} \mathrm{~mol} \mathrm{~L}^{-1} \mathrm{~K}_{2} \mathrm{Cr}_{2} \mathrm{O}_{7}$ in $2.00 \mathrm{~mol} \mathrm{~L}^{-1} \mathrm{H}_{2} \mathrm{SO}_{4}$ were added to cell at $(60 \pm 1)$ ${ }^{\circ} \mathrm{C}$ controlled temperature. Aliquots of $0.500 \mathrm{~mL}$ of minoxidil solutions were added to the $\mathrm{K}_{2} \mathrm{Cr}_{2} \mathrm{O}_{7}$ solution in acid media from a $10.00 \mathrm{~mL}$ full capacity burette. After each addition of titrant the system was let to stabilize during 3 minutes, before the potential measurement.

\section{Commercial Samples}

The commercial samples used in this work were Regaine $^{\circledR}$ from Pharmacia (USA) and Neoxidi $l^{\circledR}$ from Galderma (Brazil); both purchased in the local market. Samples were topic use formulations of minoxidil $2 \%\left(20 \mathrm{mg} \mathrm{mL}^{-1}\right)$ in a mixture of ethanol and propylene glycol as vehicle.

As observed in test titrations both propylene glycol and ethanol present in the commercial samples severely interfered in the minoxidil determinations. Thus they were removed first by evaporation of ethanol in a rotary evaporator at $70^{\circ} \mathrm{C}$ under reduced pressure followed by addition of acetone to the resulting viscous liquid. At this point minoxidil precipitates as a white solid that was recovered by filtration in a glass plate funnel. The precipitate was dried at $60^{\circ} \mathrm{C}$ in an oven during 30 minutes and dissolved in $2.00 \mathrm{~mol} \mathrm{~L}^{-1}$ $\mathrm{H}_{2} \mathrm{SO}_{4}$ and then titrated.

\section{Comparison Method}

In order to check the accuracy of the proposed procedure the results were compared with those from a chromatographic procedure describe by Zarghi et al. [8], using a HPLC LC-6AD Shimadzu chromatographic system with a SPD-10A VP Shimadzu spectrophotometric detector, Supelco C-18 (150 x $3.9 \mathrm{~mm}, 4 \mathrm{~mm})$ column, detection at $254 \mathrm{~nm}$, mobile phase methanol / water $(80 / 20)$ flowing at $1.3 \mathrm{~mL} \mathrm{~min}^{-1}$.

\section{Results and Discussion}

The redox reaction between the $\mathrm{K}_{2} \mathrm{Cr}_{2} \mathrm{O}_{7}$ and minoxidil was very slow at $25^{\circ} \mathrm{C}$. However significant stabilization of the potential was observed when the system was held for 3 minutes after each addition of the titrant at $60^{\circ} \mathrm{C}$. The effect of temperature on the redox titration profile was investigated for $40,50,60$ and $70^{\circ} \mathrm{C}$, as shown in Figure 2. The profiles of potentiometric curves and the end points of each titration were compared

Sousa et al. Fig.2

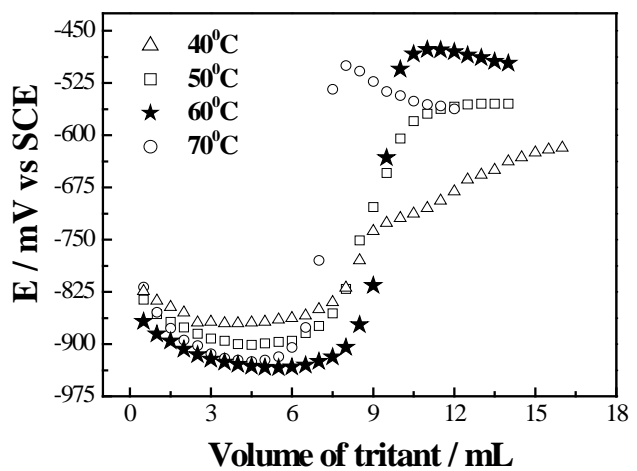

The best results for the potentiometric curve shape and accuracy of the end point were reached at $60^{\circ} \mathrm{C}$ (Figure 2). Equation 2 gives a sug- 
gestion for the reaction between the minoxidil and $\mathrm{K}_{2} \mathrm{Cr}_{2} \mathrm{O}_{7}$.

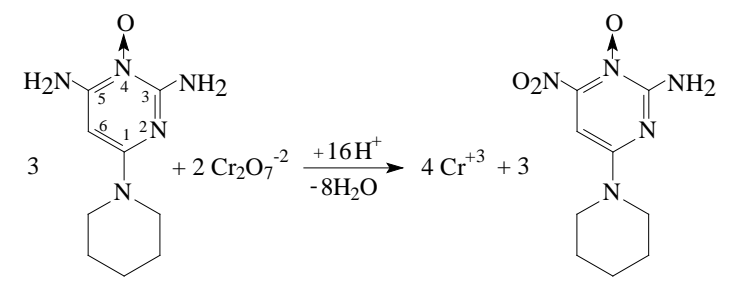

(Eq.2)

This suggestion is based on the stoichiometry of the titration in which 2 mols of $\mathrm{Cr}_{2} \mathrm{O}_{7}{ }^{2-}$ are consumed by 3 mols of minoxidil. The oxidation of the amine group at position 5 of the aromatic ring is proposed considering the lower reactivity of the amine group in position 3 .

\section{Sample Determinations}

The titrant addition resulted in a potential change of the platinum electrode. To better identify the end point of potentiometric titrations the Gram method was used [17] which consists of a $\Delta \mathrm{E} / \Delta \mathrm{V}$ vs volume of titrant added curve, in whi- ch the intersection between the two linear portions indicates the end point of the titration, see Figure 3 for an example.

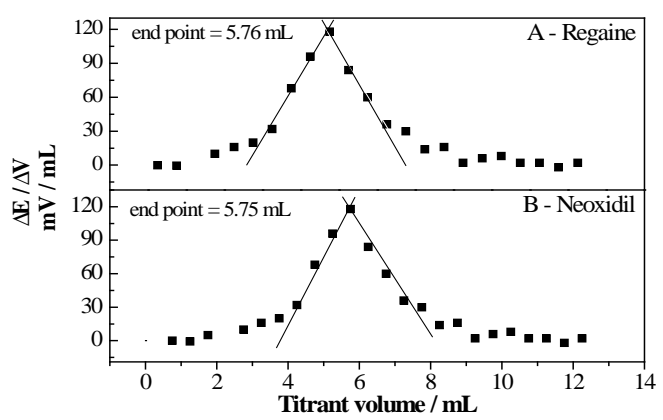

Sousa et al. Fig.3

The values of minoxidil concentration (Table 1) contained in the commercial samples were consistent with the label values. The proposed method agrees in $90 \%$ confidence level, with the label value of commercial samples and $95 \%$ confidence level, with the values obtained by the comparative chromatographic method, according to the Student t-test [18].

Table 1: Results of potentiometric titrations

\begin{tabular}{cccccc}
\hline Samples & Label $^{\boldsymbol{a}}$ & Found $^{\boldsymbol{b}^{*}}$ & Comparison $^{\boldsymbol{b}^{*}}$ & $\boldsymbol{E}_{1} / \boldsymbol{\%}^{\boldsymbol{c}}$ & $\boldsymbol{E}_{2} / \boldsymbol{\%}^{\boldsymbol{d}}$ \\
\hline Neoxidil $^{\circledR}$ & 20.0 & $20.7 \pm 0.2$ & $19.4 \pm 0.4$ & +3.72 & +6.70 \\
Regaine $^{\circledR}$ & 20.0 & $21.0 \pm 0.3$ & $20.9 \pm 0.5$ & +4.71 & +0.48 \\
\hline
\end{tabular}

${ }^{*} \mathrm{n}=3$

$\mathrm{a}-$ Concentration in $\mathrm{mg} \mathrm{mL}^{-1}$

$\mathrm{b}-$ Concentration in $\mathrm{mg} \mathrm{mL}^{-1} \pm \mathrm{SD}$

c - Relative error to the label

d - Relative error to the comparison methods

In order to evaluate the accuracy of the proposed method recovery tests were performed with recoveries between $98.7 \%$ for Neoxidil $^{\circledR}$ and 97.4\% for Regaine ${ }^{\circledR}$. 


\section{FIGURE CAPTIONS}

Figure 1: Structural formula of minoxidil.

Sousa et al. Fig.1

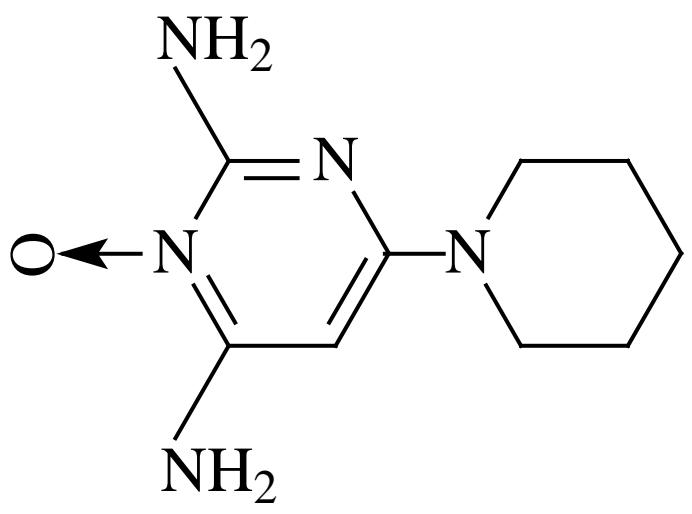

Figure 2: Effect of the temperature in the potentiometric titration.

Conditions: [minoxidil] $=1,00 \times 10^{-2} \mathrm{~mol} \mathrm{~L}^{-1}$; $\left[\mathrm{K}_{2} \mathrm{Cr}_{2} \mathrm{O}_{7}\right]=1,00 \times 10^{-2} \mathrm{~mol} \mathrm{~L}^{-1}$; Volume of $\mathrm{K}_{2} \mathrm{Cr}_{2} \mathrm{O}_{7 \text { (aq) }}$; $=3,00 \mathrm{~mL}$; $\left[\mathrm{H}_{2} \mathrm{SO}_{4}\right]=2,00 \times 10^{-2} \mathrm{~mol} \mathrm{~L}^{-1}$; Volume of $\mathrm{H}_{2} \mathrm{SO}_{4(\mathrm{aq})}=5 \mathrm{~mL}$; Stabilization time $=3$ minutes.

Figure 3: Identication of the end point of the potentiometric titration (Gram's method) of the commercial samples; A - Regaine ${ }^{\circledR}$; B - Neoxidil ${ }^{\circledR}$. Conditions: [minoxidil] $=1,00 \times 10^{-2} \mathrm{~mol} \mathrm{~L}^{-1} \cdot\left[\mathrm{K}_{2} \mathrm{Cr}_{2} \mathrm{O}_{7}\right]=$ $1,00 \times 10^{-2} \mathrm{~mol} \mathrm{~L}^{-1}$; Volume of $\mathrm{K}_{2} \mathrm{Cr}_{2} \mathrm{O}_{7(\mathrm{aq})}$; $=3,00 \mathrm{~mL}$;
$\left[\mathrm{H}_{2} \mathrm{SO}_{4}\right]=2,00 \times 10^{-2} \mathrm{~mol} \mathrm{~L}^{-1}$; Volume of $\mathrm{H}_{2} \mathrm{SO}_{4(\mathrm{aq})}=$ $5 \mathrm{~mL}$; Stabilization time $=3$ minutes; $\mathrm{T}=60^{\circ} \mathrm{C}$.

\section{Conclusions}

The method proposed in this study was effective in the determination of minoxidil in commercial samples for topical applications, considering the apparatus limits and errors inherent to the classical technique.

Although time consuming, this procedure can be an alternative for quality control in the magistral pharmacies, presenting low cost and good precision when compared with other more expensive and waste generating methods as chromatography,.

\section{Acknowledgements}

The authors are grateful to Brazilian agencies CAPES and CNPq for RAS and ETGC fellowships.

Determinação Potenciométrica De Minoxidil Em Formulações Farmacêuticas De Uso Tópico

Received November 032008

Accepted October 142009

Resumo: Um método potenciométrico para a determinação de minoxidil em formulações farmacêuticas baseado na reação redox entre $\mathrm{K}_{2} \mathrm{Cr}_{2} \mathrm{O}_{7}$ e o minoxidil, foi desenvolvido. Os melhores resultados foram obtidos usando concentrações de $1,00 \times 10^{-2} \mathrm{~mol} \mathrm{~L}^{-1}$ para o minoxidil e $1,00 \times 10^{-3}$ mol L-1 para o $\mathrm{K}_{2} \mathrm{Cr}_{2} \mathrm{O}_{7}$ ambos diluídos em uma solução em de $\mathrm{H}_{2} \mathrm{SO}_{4} 2,00$ mol L-1, a $60^{\circ} \mathrm{C}$. As recuperações para método proposto foram da ordem de $98,7 \%$ a 97,4 \% dependendo da amostra comercial. O método proposto foi aplicado à amostras comerciais contendo minoxidil e, quando comparado com resultados obtidos a partir de procedimentos cromatográficos, apresentou concordância no nível de confiança de 95\%, de acordo com o teste t-Student.

Palavras chave: Determinação minoxidil; titulação; potenciometria. 


\section{References}

[1] S. S. Budavari, M.J. O’Neil, A. Smith, P.E. Heckelman, J.F. Kinneary, The Merck Index, 13th , erck \& Company Incorporated, Whitehouse Station, New Jersey, 2001, 6229p.

[2] Amankwa, L.; Chatten, L.G.; Pons, S.; "Electrochemical studies on minoxidil and determination in tablets by differential-pulse polarography” Analyst, 108: 1221, 1983.

[3] Ruiz-Medina, A.; Fernandez-de Cordova, M.L.; MolinaDiaz, A.; "Integrated flow injection-solid phase spectrophotometric determination of minoxidil”. Talanta, 50 (2): 277, 1999. [4] J. H. Han, O. S. Kwon, J. H. Chung, K. H. Cho, H. C. Eun, K. H. Kim, J. Dermatol. Sci., 34 (2004) 91.

[5] W. Z. Zhong, P. E. Sanders, M. J. Hauer, J. J. Vrbanae, J.Chromatogr. B, 705 (1998) 39.

[6] W. Z. Zhong, J. Pharm. Biomed. Anal., 16 (1998) 1179.

[7] Sousa, R. A.; Semaan, F.S.; Fragali, J.A.B.; Cavalheiro E.T.G.; "Fast Determination of Minoxidil by Photometric Flow Titration”. Eclética Química, 30 (3): 79, 2005.

[8] Sousa, R. A.; Calheiro E.T.G.; "Determinação de minoxidil em formulações farmacêuticas usando permanganometria”. Eclética Química, submitted.

[9] Zarghi, A.; Jenabi, M.; Ebrahimian, A. J. " HPLC determination of the tretonoin-minoxidil solution" Pharm. Acta Helvet., 73: 163, 1998.

[10] Fanali, S.; Cristalli, M.; Catellani, P.; "Determination of minoxidil in pharmaceutical forms by capillary isotachophoresis”. J. Chromatogr. A, 405: 385, 1987.

[11] G. Carrum, D.R. Abernethy, M.S.C.E. Wright, J. Chromatogr. B, 381 (1986) 127.

[12] Zarghi, A.; Shafaati, A.; Foroutan, S.M.; Khoddam, A.; "Rapid determination of minoxidil in human plasma using ion-pair HPLC”. J. Pharm. Biomed. Anal, 36: 377, 2004.

[13] Skoog, D.A.; Holler, F.J.; Nieman, T.A.; Princípios de Análise Instrumental, quinta edição, 548, Artmed editora S.A, 2002.

[14] Jeffery, G.H.; Bassett, J.; Mendham, J.; Denney, R.C.; Vogel. Análise Química Quantitativa, quinta edição, 436, LTC, 1992.

[15] Jeffery, G.H.; Bassett, J.; Mendham, J.; Denney, R.C.; Vogel. Análise Química Quantitativa; quinta edição; 268; LTC Ltda. 1992

[16] Skoog, D.A.; Holler, F.J.; Nieman, T.A.; Princípios de Análise Instrumental, quinta edição, 548, Artmed editora S.A, 2002.

[17] Gran, G.; "Determination of the equivalent point in potentiometric titrations". Acta Chemica Scandinavica, 4: 559, 1950.

[18] Harris, D.C. Análise Química Quantitativa, quinta edição, 61, LTC - Livros técnicos e Científicos Editora AS, 2001. 5: 39, 1998. 